Article

\title{
Brachycorynella asparagi (Mordv.) Induced-Oxidative Stress and Antioxidative Defenses of Asparagus officinalis L.
}

\author{
Beata Borowiak-Sobkowiak ${ }^{1}$, Agnieszka Woźniak ${ }^{2}$, Waldemar Bednarski ${ }^{3}$, Magda Formela ${ }^{2}$, \\ Sławomir Samardakiewicz ${ }^{4}$ and Iwona Morkunas ${ }^{2, *}$ \\ 1 Department of Entomology and Environmental Protection, Poznań University of Life Sciences, \\ Dąbrowskiego 159, Poznań 60-594, Poland; borowiak@up.poznan.pl \\ 2 Department of Plant Physiology, Poznań University of Life Sciences, Wołyńska 35, Poznań 60-637, Poland; \\ agnieszkam.wozniak@gmail.com (A.W.); formelamagda@o2.pl (M.F.) \\ 3 Institute of Molecular Physics, Polish Academy of Sciences, Smoluchowskiego 17, Poznań 60-179, Poland; \\ Waldemar.Bednarski@ifmpan.poznan.pl \\ 4 Laboratory of Electron and Confocal Microscopy, Faculty of Biology, Adam Mickiewicz University, \\ Umultowska 89, Poznań 61-614, Poland; sas@amu.edu.pl \\ * Correspondence: morkunas@up.poznan.pl; Tel.: +48-618-466-040; Fax: +48-618-487-179
}

Academic Editors: Massimo Maffei and Francesca Barbero

Received: 11 August 2016; Accepted: 11 October 2016; Published: 20 October 2016

\begin{abstract}
The aim of this study was to investigate whether and to what extent oxidative stress is induced in leaves of one- and two-month-old plants of Asparagus officinalis L. cv. Argenteuil infested by Brachycorynella asparagi (Mordvilko) at a varied population size. The pest $B$. asparagi has been described as the most damaging species feeding on asparagus. Analyses using electron paramagnetic resonance (EPR) demonstrated generally higher concentrations of semiquinone radicals with $g$-values of $2.0045 \pm 0.0005$ and $2.0026 \pm 0.0005$ in Asparagus officinalis (A. officinalis) leaves after Brachycorynella asparagi (B. asparagi) infestation than in the control. Observations of leaves under a confocal microscope showed a post-infestation enhanced generation of the superoxide anion radical $\left(\mathrm{O}_{2}{ }^{--}\right)$and hydrogen peroxide $\left(\mathrm{H}_{2} \mathrm{O}_{2}\right)$ in comparison to the control. Strong fluctuations in $\mathrm{Mn}^{2+}$ ion levels detected by EPR spectroscopy versus time were detected in leaves infested by aphids, which may indicate the involvement of these ions in the control of $\mathrm{O}_{2}{ }^{\bullet-}$ production. An enhanced superoxide dismutase activity is an important element in leaf defense against oxidative stress. Visible symptoms were found in aphid-infested A. officinalis. Damage to leaves of one- and two-month-old A. officinalis plants by the aphid B. asparagi was dependent on the intensity, duration of infestation and plant age.
\end{abstract}

Keywords: Brachycorynella asparagi; Asparagus officinalis; semiquinone radicals; manganese ions; reactive oxygen species; oxidative stress; antioxidant enzymes

\section{Introduction}

Asparagus (Asparagus officinalis) is a perennial plant of the family Liliaceae. Since antiquity [1], asparagus has been cultivated as a vegetable crop for its succulent stalks (spears). Additionally, Asparagus was used in medicine (from which its species derived its name officinalis) for its diuretic properties [2]. China is the largest asparagus producer with almost $90 \%$ of the world production. In Europe, Spain is the first producer in the Mediterranean area, followed by Italy and France. Moreover, A. officinalis has also been cultivated in Poland for decades. Asparagus plants are colonized by a number of pests. Aphids, including the species Brachycorynella, infest aerial parts of the plant [3]. The European asparagus aphid, Brachycorynella asparagi (Mordvilko), is a major pest of garden asparagus. Feeding of 
the asparagus aphid causes a characteristic severe distortion of the terminal bud, called "rosetting" of Asparagus ferns, with the internodes being shortened and the leaves being both shortened and turning blue green. Strong aphid infestation on asparagus can cause dieback of seedlings [4]. Affected stems of mature plants are weakened; they develop imperfectly, become stunted and broom-like, with plants growing in the shape of a bush. Phytophagous insects represent a significant problem in global agriculture, causing yield reductions across all major agricultural areas and leading to costs incurred for control measures [5].

In the present study, we showed how an attack of Brachycorynella asparagi (B. asparagi) at a varied population size influences defense reactions, their intensity versus time of infestation, in leaves of one- and two-month-old Asparagus officinalis (A. officinalis) plants. Identification of defense responses in leaves of different $A$. officinalis ages in the context of the level of the oxidative stress and antioxidant defense against $B$. asparagi is a completely novel approach. The results of this study for the first time show the relative generation and the subcellular localization of reactive oxygen species (ROS) in A. officinalis leaves infested by B. asparagi. Superoxide anion radical $\left(\mathrm{O}_{2}{ }^{\bullet-}\right)$ and other ROS may be generated by cyclic reduction/oxidation of quinones, which may be reduced intracellularly to their semiquinones [6]. Moreover, post-infestation changes in concentrations of semiquinone radicals and manganese ions $\left(\mathrm{Mn}^{2+}\right)$ in the above-mentioned system were revealed. Manganese, as a cofactor of superoxide dismutase (SOD) can participate in the plant's defense against oxidative stress. In the available literature, there is practically no information regarding post-infestation changes of $\mathrm{Mn}^{2+}$ ions in plant response to aphid infestation.

The signs and symptoms of aphid attack can be diverse and vary depending on the plant species (and the tissue attacked), the aphid species and biotype, and their combination [7]. Plant survival upon herbivore attack depends on a multicomponent protection strategy, involving constitutive and inducible defenses [8,9]. The recognition of infestation activities by plants can occur through the use of transmembrane pattern recognition receptors (PRRs) or, acting largely inside the cell, polymorphic nucleotide-binding site-leucine-rich repeat (NBS-LRR) protein products, encoded by most resistant genes [10]. Recently new evidence for the involvement of PAMP (Pathogen Associated Molecular Pattern)-triggered immunity (PTI) in plant-aphid interactions was revealed by Jaouannet et al. [11]. Early plant responses to attacks by phytophagous insects or by pathogens share common events, such as protein phosphorylation, membrane depolarization, calcium influx and release of ROS, e.g., $\mathrm{O}_{2}{ }^{\bullet-}$ and hydrogen peroxide $\left(\mathrm{H}_{2} \mathrm{O}_{2}\right)$ [12]. Enhanced production of ROS or differential expression changes of genes involved in the oxidative stress in plants during feeding by aphids were found in several aphid-host systems [13-16]. An increased expression of respiratory burst oxidase homolog (RBOH), that plays an important role in ROS-mediated signaling, was also noted in aphid-infested leaves [17].

Amongst all, $\mathrm{O}_{2}{ }^{\bullet-}$ and $\mathrm{H}_{2} \mathrm{O}_{2}$ are two ROS that have been given more importance in recent studies [18]. It has been established that $\mathrm{H}_{2} \mathrm{O}_{2}$ acts as a secondary messenger in signal transduction networks. Therefore, as it was reported by Maffei et al. [19,20], $\mathrm{H}_{2} \mathrm{O}_{2}$ is one of the most important ROS in the plant-pathogens/herbivore interactions and has an important role in signal transmission and in plant defense responses. Moreover, Mai et al. [16] reported that an early, strong generation of $\mathrm{H}_{2} \mathrm{O}_{2}$ may be related to its function as a signaling molecule, triggering defense mechanisms in pea leaves against A. pisum. Additionally, herbivore damage leads to the accumulation of secondary metabolites [21] and defensive proteins, including catalase (CAT), superoxide dismutase (SOD), peroxidase (POD), etc. [22]. As it was reported by Liang et al. [17], the expression pattern of some genes involved in the ROS scavenging system significantly changed after aphid infection. It has been widely reported that insect feeding influences the activities of plant defense enzymes and is associated with host resistance [23]. An unfavorable balance between ROS production and the plant antioxidant capacity seems to be responsible for the resulting susceptibility of the plant to insect attack [24]. The balance between ROS and antioxidant production determines the oxidative status of both plants and aphids, which in turn might influence aphids' ability to infest new plants. Therefore, as it was reported by War et al. [25], the successful defense of plants against the biotic stresses depends on their ability to 
quickly perceive the incoming stimuli, decode them and build a strong morphological, physiological, and/or biochemical shield against the invaders. The oxidative state of the host plants is an important component of host plant resistance to insects [26-29].

The main objective of the present study was to examine whether and to what degree oxidative stress is induced in leaves of one- and two-month-old Asparagus officinalis L. cv. Argenteuil plants infested by Brachycorynella asparagi (Mordv.) at a varied population size (10, 20, 30 aphids per plant). Therefore, firstly we investigated the effects of B. asparagi on changes in the redox status of plants of cells, i.e., the concentration of semiquinone radicals and the levels of $\mathrm{Mn}^{2+}$ ions using electron paramagnetic resonance spectroscopy (EPR). The second goal was to determine relative generation and location of the superoxide anion radical and hydrogen peroxide in A. officinalis leaves infested by B. asparagi. Moreover, the third goal of the study was to determine superoxide dismutase activity, which is one of the most important antioxidative enzymes. It catalyzes the dismutation of the superoxide anion radical into hydrogen peroxide $\left(\mathrm{H}_{2} \mathrm{O}_{2}\right)$ and molecular oxygen $\left(\mathrm{O}_{2}\right)$. We also compared symptoms of $B$. asparagi infestation on A. officinalis, in this case one- and two-month-old A. officinalis L. cv. Argenteuil plants.

\section{Results}

2.1. Concentrations of Free Radicals and $\mathrm{Mn}^{2+}$ Ions Detected Using Electron Paramagnetic Resonance Spectroscopy in Asparagus officinalis Infested by Brachycorynella asparagi

Analyses of electron paramagnetic resonance (EPR) revealed the presence of free radicals, which give signals with two $g$-values, $2.0045 \pm 0.0005$ and $2.0026 \pm 0.0005$, both in the non-infested and B. asparagi infested leaves of one- and two-month-old plants (Figure 1a,b), while signals of $\mathrm{Mn}^{2+}$ ions were recorded with $g$-values of 2.00 (0.01) in both types of these leaves (Figure 1c,d). Strong fluctuations were observed when analyzing changes in semiquinone radicals and in $\mathrm{Mn}^{2+}$ ions in the function of time in A. officinalis leaves infested by aphids and the controls. At the early stage of infestation ( $24 \mathrm{hpi})$ in leaves of one- and two-month-old plants infested by 20 and 30 aphids the level of semiquinone radicals was generally significantly lower in relation to the control (Figure $1 \mathrm{a}, \mathrm{b}$ ). In contrast, only in 24-h leaves of one- and two-month-old plants infested by 10 aphids the concentration of these radicals was higher than in the control plants; it was particularly visible in leaves of two-month-old plants. From 48 hpi after infestation the levels of these radicals were higher than in leaves not infested by aphids. The highest concentration of semiquinone radicals $\left(12.29 \times 10^{14}\right.$ spins.g ${ }^{-1}$ dry wt.) was demonstrated in 48 -h leaves of one-month-old plants infested by 30 aphids (Figure 1a), while in two-month-old A. officinalis leaves infested by 30 aphids the highest levels of these radicals $\left(16.76 \times 10^{14}\right.$ spins. ${ }^{-1}$ dry wt.) were recorded at $72 \mathrm{hpi}$ (Figure $\left.1 \mathrm{~b}\right)$. In those infested leaves their concentrations were 1.5- and about 2.5-fold higher than in the control samples, respectively. Additionally, it is noticeable that in 72-h leaves of two-month-old plants infested by aphids the concentrations of semiquinone radicals were significantly higher in all infested variants than in the control plants and these levels were proportional to population sizes of aphids colonizing pea seedlings (Figure 1b). Moreover, when analyzing changes of these radicals in these leaves versus time it was observed that from 0 hpi up to 48 hpi their levels increased in leaves of one-month-old plants infested by 30 aphids (Figure 1a), followed by a drastic drop, although their level remained higher than in controls. In contrast, in leaves of one-month-old plants infested by 10 and 20 aphids we found a decrease in the level of semiquinone radicals from 24 to $72 \mathrm{hpi}$, after which at $96 \mathrm{hpi}$ the level increased considerably and the concentration was higher than in the control plants. In turn, between 72 and $96 \mathrm{~h}$ after infestation a marked decrease was observed in the concentrations of semiquinone radicals in two-month-old $A$. officinalis leaves infested by aphids at a varied population size, with their levels remaining significantly higher than in the control (Figure 1b). Significant differences were observed between the applied experimental variants, i.e., leaves infested by aphids and the control, as revealed by ANOVA. 
In turn, when analyzing changes in the level of $\mathrm{Mn}^{2+}$ ions it was found to decrease in 24-h leaves of one-month-old plants infested by aphids at a varied population size and in 24-h leaves of two-month-old plants infested by 20 aphids relative to the control (Figure 1c,d). Next, we need to stress a significant increase in $\mathrm{Mn}^{2+}$ ions in 48-h leaves of one-month-old plants infested by 30 aphids, as the level of these ions was 1.7 higher than in the control leaves. In turn, in the case of leaves of one-month-old plants infested by 10 aphids the highest concentration of these ions was recorded at $72 \mathrm{hpi}$. In the case of leaves infested by 20 aphids the highest concentration of $\mathrm{Mn}^{2+}$ ions was found at $96 \mathrm{hpi}$. Therefore, the levels of $\mathrm{Mn}^{2+}$ ions in those infested leaves were about 1.4 and 1.6 higher than in the control leaves, respectively (Figure 1c). ANOVA showed differences in these results to be highly significant. In leaves of one-month-old plants treated with 10, 20 and 30 aphids the levels of $\mathrm{Mn}^{2+}$ ions were $(2.2-3.01) \times 10^{15},(2.2-3.34) \times 10^{15}$ and (2.2-3.6) spins. ${ }^{-1}$ dry wt., respectively, while they ranged from 2.09 to $2.93 \times 10^{15}$ spins. ${ }^{-1}$ dry wt. in the control leaves (Figure 1c). In turn, in leaves of two-month-old plants infested by 10, 20 and 30 aphids the levels of $\mathrm{Mn}^{2+}$ ions were $(2.55-5.40) \times 10^{15}$, $(2.55-5.97) \times 10^{15}$ and $(2.55-6.18) \times 10^{15}$ spins.g ${ }^{-1}$ dry wt., respectively, while they ranged from 2.55 to $4.46 \times 10^{15}$ spins. ${ }^{-1}$ dry wt. in the control leaves (Figure 1d). It should be emphasized here that in leaves of two-month-old plants infested by aphids at a varied population size significant changes were observed in the function of time.

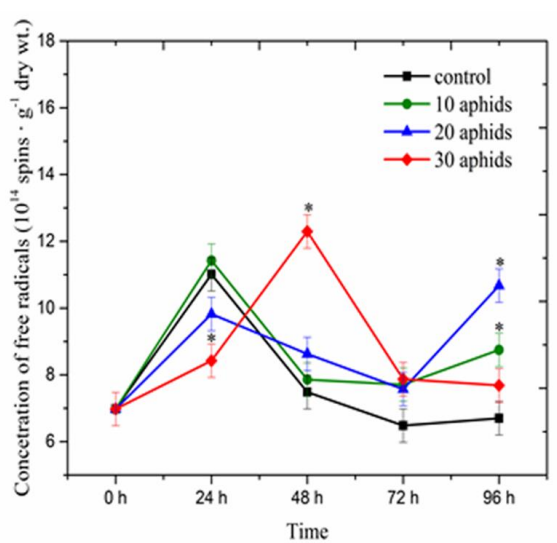

(a)

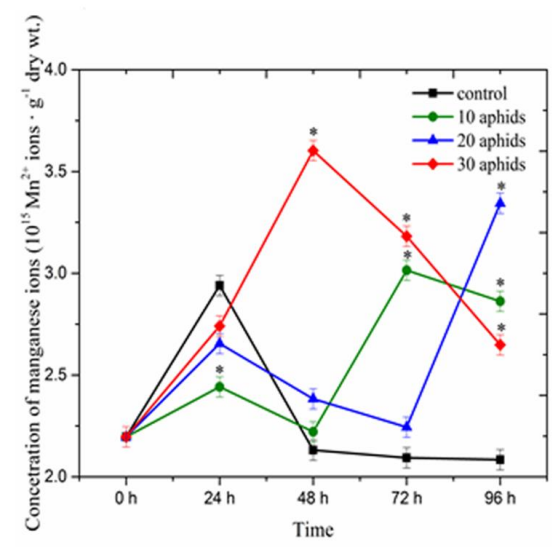

(c)

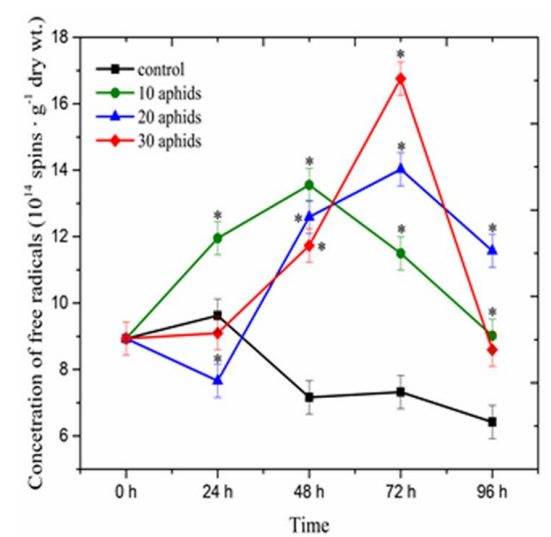

(b)

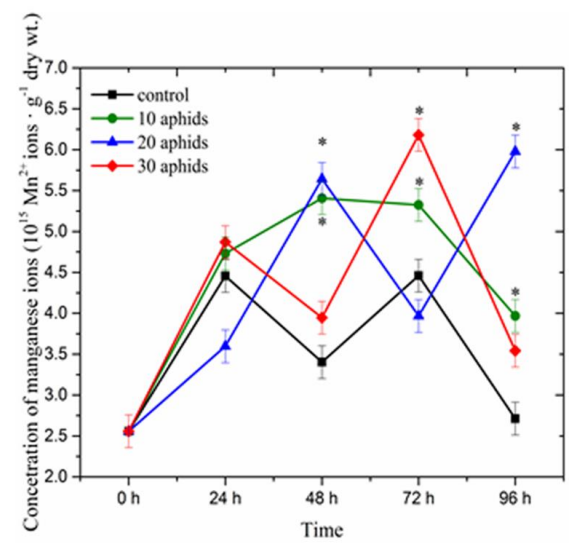

(d)

Figure 1. Concentrations of semiquinone radicals with two $g$-values: $2.0045 \pm 0.0005$ and $2.0026 \pm 0.0005(\mathbf{a}, \mathbf{b})$; and manganese ions with $g$-values of $2.00(0.01)(\mathbf{c}, \mathbf{d})$ in leaves of one- and two-month-old plants of Asparagus officinalis L. cv. Argenteuil infested by Brachycorynella asparagi (Mordvilko) at a varied population size (10,20, and 30 aphids per plant). Values represent means and SE from three independent experiments. The data was statistically analyzed using analysis of ANOVA variance ( $p$-values at $\alpha=0.05$ ). In individual figures significant differences are shown using asterisks. 
2.2. The Effect of Brachycorynella asparagi Infestation on the Generation of the Superoxide Anion Radical in Asparagus officinalis

Brachycorynella asparagi infestation caused generation of the superoxide anion radical in A. officinalis leaves of both one- and two-month-old plants (Figure 2a-c). Relative release of $\mathrm{O}_{2}{ }^{\bullet-}$ was investigated by staining leaves with the superoxide anion-specific indicator, dihydroethidium (DHE). The presence of $\mathrm{O}_{2}{ }^{\bullet-}$ oxidizes DHE to ethidium, whereupon it emits fluorescence. On the surface of the leaves in the epidermal layer single points of $\mathrm{O}_{2}{ }^{--}$generation were visible. However, most of those places are visible on leaves infested by 20 and 30 aphids. Starting from $24 \mathrm{~h}$ in leaves infested by B. asparagi the production of $\mathrm{O}_{2}{ }^{\bullet-}$ increased markedly with the duration of feeding time. The strongest generation was observed in 96-h leaves of one-month-old plants infested by 30 aphids. Additionally, it is noticeable that in these leaves infested by 30 aphids relative generation of $\mathrm{O}_{2}{ }^{\bullet-}$ was significantly higher than in the control plants and in other infested variants (Figure 2a,c). Moreover, in 96-h leaves of one-month-old plants infested by 30 aphids the generation of $\mathrm{O}_{2}{ }^{--}$was visible mostly in the cytoplasm and sporadically in the regions of cell walls (Figure 2c). In turn, in leaf cells of two-month-old plants the generation of $\mathrm{O}_{2}{ }^{\bullet-}$ increased markedly from $48 \mathrm{~h}$ (Figure $2 \mathrm{~b}$ ). In addition, relative generation of $\mathrm{O}_{2}{ }^{\bullet-}$ was lower in leaves of two month-old $A$. officinalis plants than the leaves of one-month-old plants.
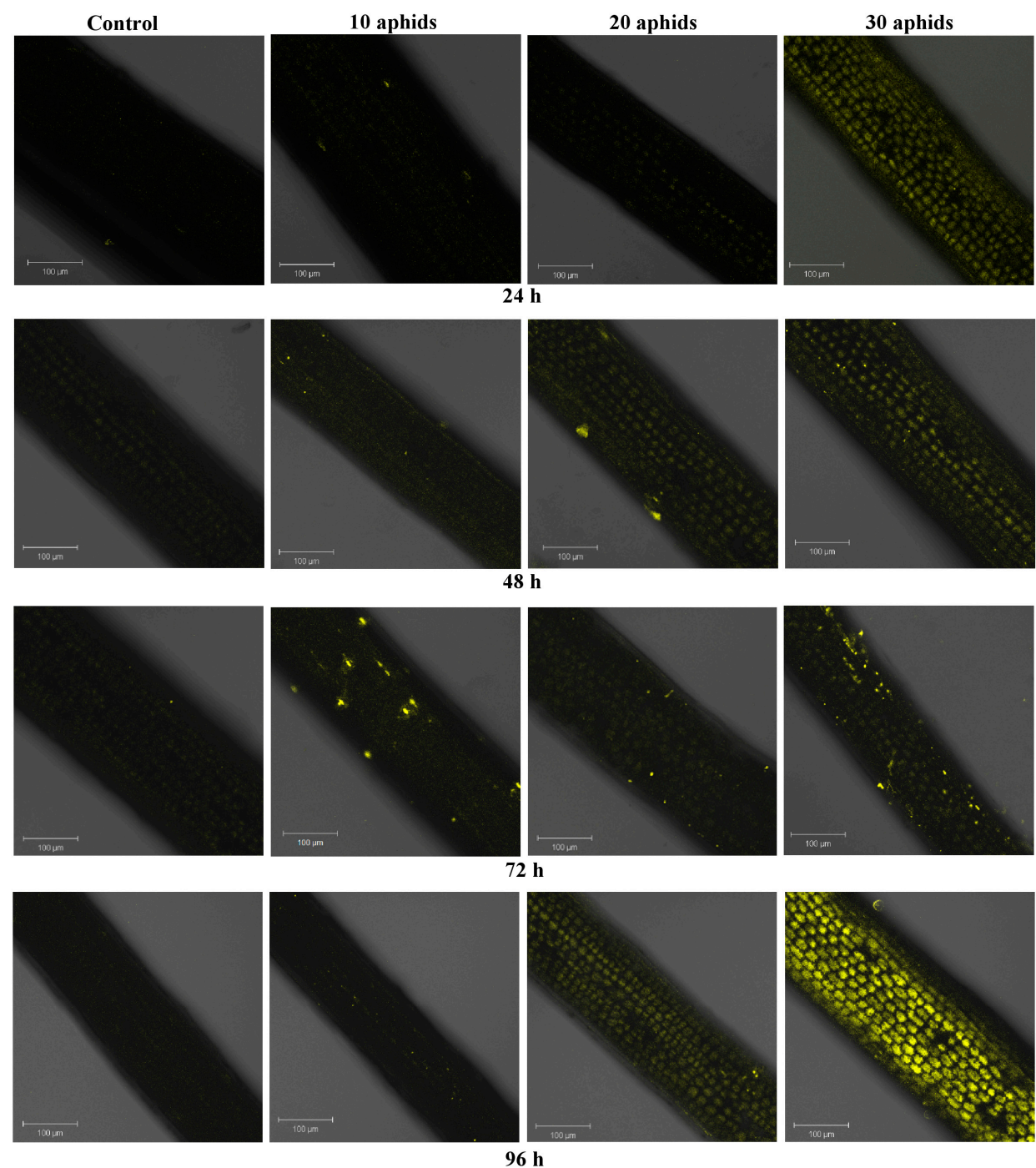

(a)

Figure 2. Cont. 

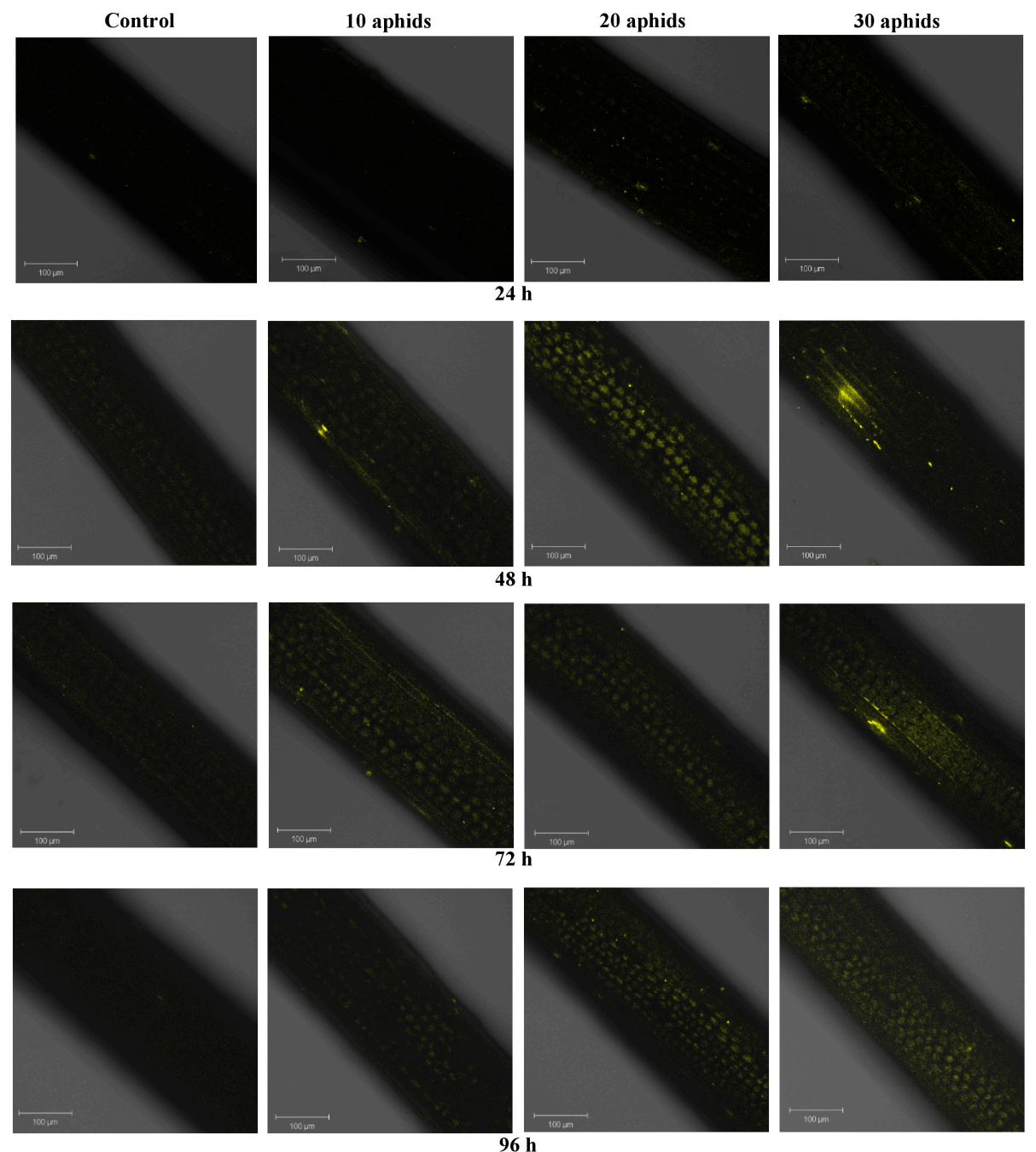

(b)
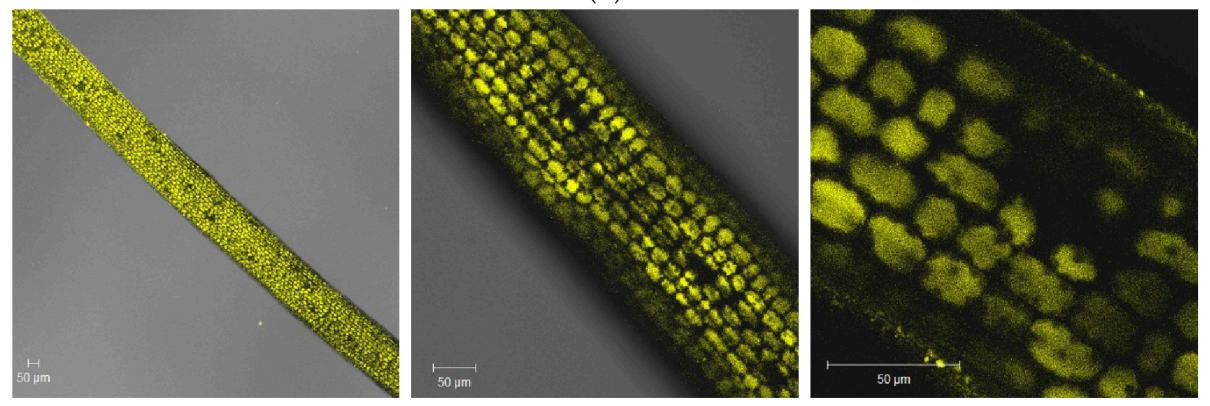

(c)

Figure 2. Relative generation and cytochemical localisation of superoxide anion radical in leaves of one- (a) and two-month-old plants (b) of Asparagus officinalis L. cv. Argenteuil infested by Brachycorynella asparagi (Mordv.) at a varied population size (10, 20, and 30 aphids per plant); and 96-h leaves of Asparagus officinalis one-month-old plants infested by 30 aphids B. asparagi per plant (c). Yellow fluorescence originating from DHE (dihydroethidium) was observed under a Zeiss LSM 510 confocal microscope (objective magnification of $20 \times$ for $\mathbf{a}, \mathbf{b}$ and $5 \times, 20 \times$ and $63 \times$, respectively, for c). Scale bar $100 \mu \mathrm{m}(\mathbf{a}, \mathbf{b})$ and $50 \mu \mathrm{m}(\mathbf{c})$. 
2.3. The Effect of Brachycorynella asparagi Infestation on the Level of Hydrogen Peroxide in Asparagus officinalis

Already at $24 \mathrm{hpi}$ in leaves of one-month-old plants infested by 20 and 30 aphids single spots of green fluorescence were visible, indicating $\mathrm{H}_{2} \mathrm{O}_{2}$ generation (Figure 3a). From 48 hpi we noted a stronger fluorescence in the function of time, which was visible in whole cells. However, in the early time of infestation of the pest $B$. asparagi the strongest generation of $\mathrm{H}_{2} \mathrm{O}_{2}$ was found in 48-h leaves of one-month-old plants infested by 30 aphids (Figure 3c). In turn, in 96-h leaves of one-month-old plants infested by 10 aphids the emission of green fluorescence was observed mainly in cell walls. Furthermore, $B$. asparagi feeding caused an increase in the generation of $\mathrm{H}_{2} \mathrm{O}_{2}$ in leaves of two-month-old plants infested by aphids, but it was noticeable starting from 72 hpi (Figure 3b). A strong emission of green fluorescence was observed in 72 and 96-h leaves of two-month-old plants infested by 30 aphids and in 96-h leaves infested by 20 aphids (Figure 3b,d). In these variants the emission of green fluorescence is most intense in the cytoplasm, while in 72-h leaves infested by 10 and 20 aphids and in 96-h leaves infested by 10 aphids this emission dominates in the area of cell walls.
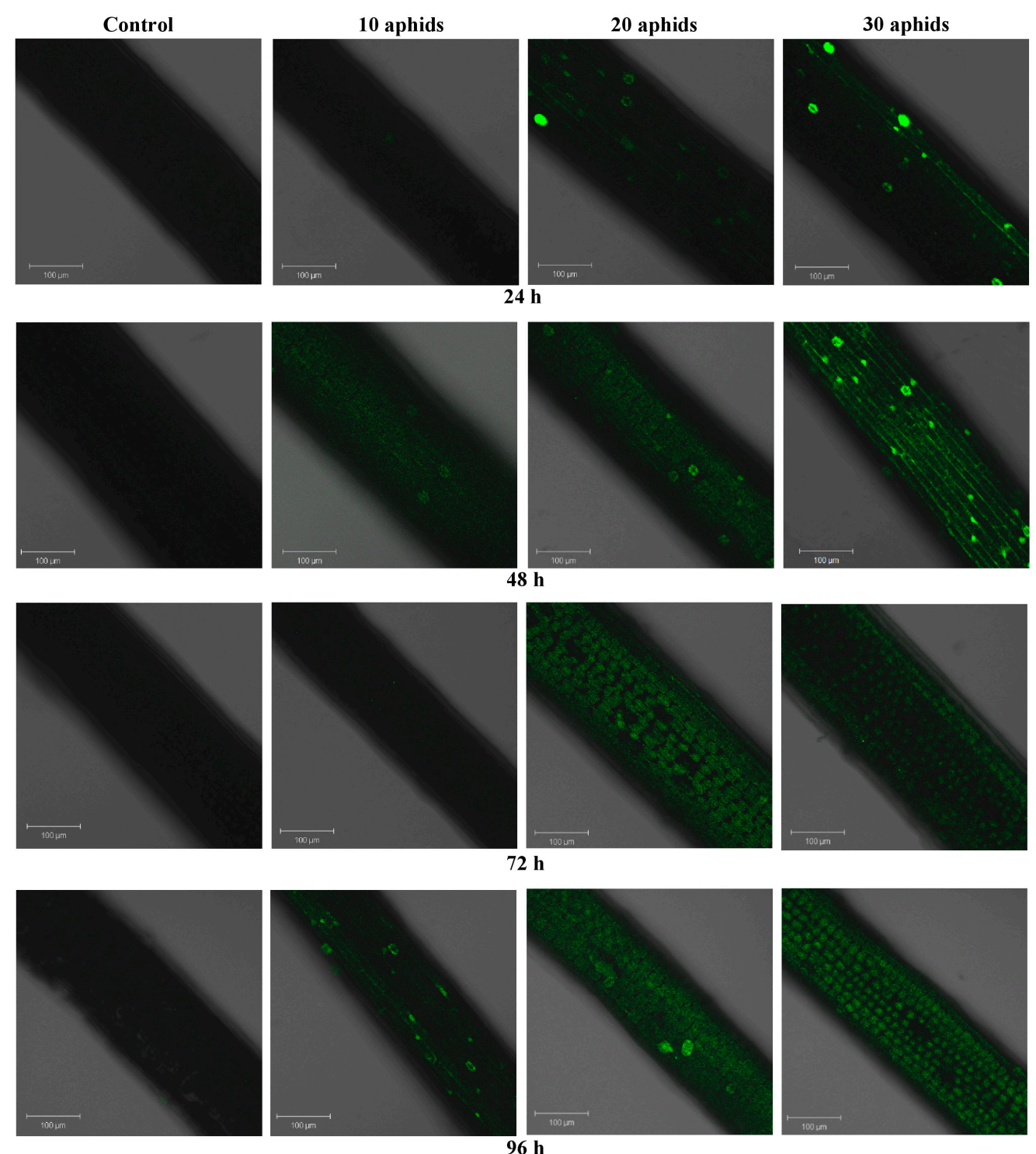

(a)

Figure 3. Cont. 

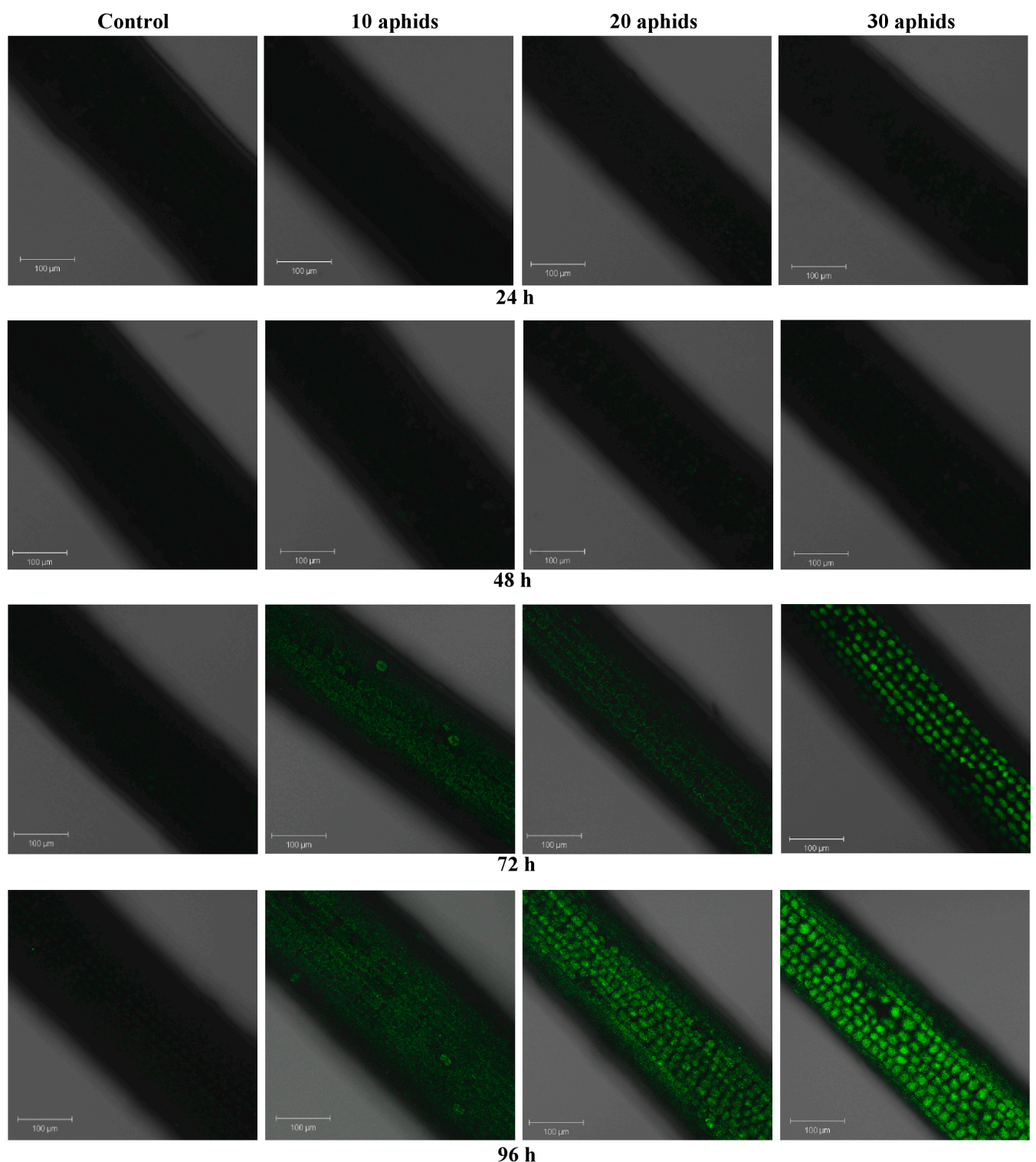

(b)
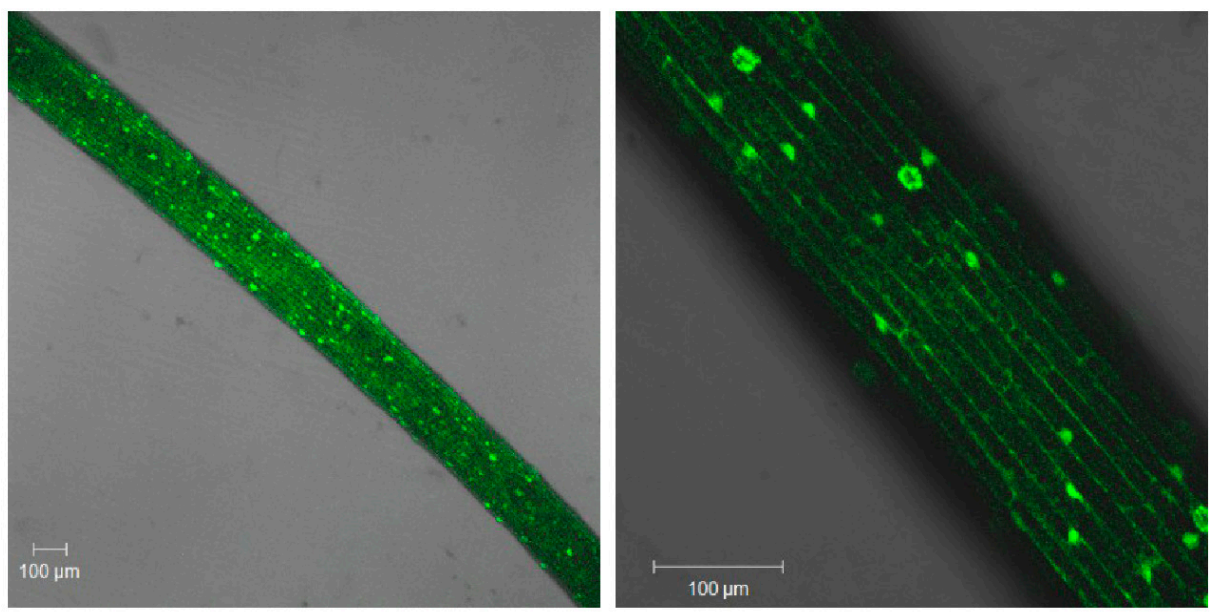

(c)

Figure 3. Cont. 

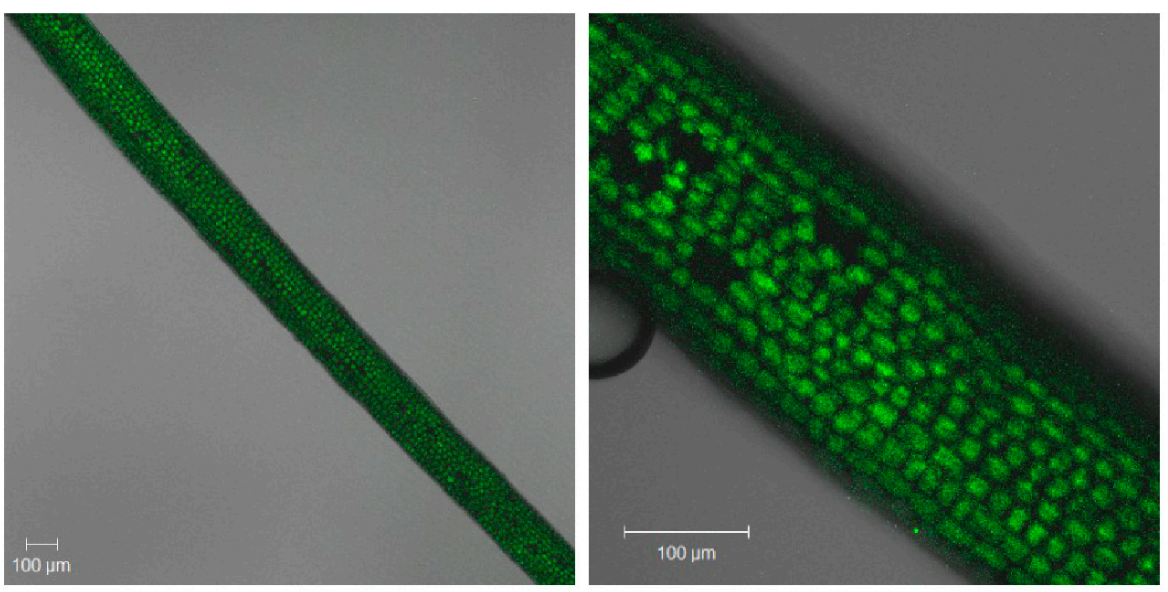

(d)

Figure 3. Relative generation and cytochemical localization of hydrogen peroxide in leaves of one- (a) and two-month-old plants (b) of Asparagus officinalis L. cv. Argenteuil infested by Brachycorynella asparagi (Mordv.) at a varied population size (10, 20, and 30 aphids per plant); 48-h leaves of Asparagus officinalis one-month-old plants infested by 30 aphids B. asparagi per plant (c); and 96-h leaves of Asparagus officinalis two-month-old plants infested by 30 aphids (d). Green fluorescence originating from DCFH-DA (dichlorodihydro-fluorescein diacetate) was observed under a Zeiss LSM 510 confocal microscope (objective magnification of $20 \times$ for $\mathbf{a}, \mathbf{b}$ and $5 \times$ and $20 \times$, respectively, for $\mathbf{c}$ ). Scale bar $100 \mu \mathrm{m}(\mathbf{a}-\mathbf{d})$.

\subsection{The Effect of Brachycorynella asparagi Infestation on the Antioxidant Enzyme Activity in Asparagus officinalis}

Analysis of changes in the activity of SOD demonstrated a different trend in leaves of one- and two-month-old plants infested by aphids and the controls (Figure 4). In one-month-old plants of A. officinalis from 0 to $96 \mathrm{hpi}$ we recorded a lower activity of this enzyme in the infested leaves than in the controls, with the exception of SOD activity in 24 and 48-h leaves infested by 20 aphids, wherein the activity of the enzyme was similar to that in the control (Figure 4a). At 72 and 96 hpi, we observed the largest reduction in the activity of the enzyme as compared to the control. In 72-h leaves infested by 10, 20 and 30 aphids, the activity of SOD was about $20 \%, 99 \%$ and $30 \%$ lower than in the control, respectively. In turn, in 96-h leaves infested by 10, 20 and 30 aphids, the activity of the enzyme was by about $28 \%, 34 \%$ and $46 \%$ lower than in the control, respectively. In contrast to SOD activity in leaves of one-month-old plants (Figure 4a), in two-month-old leaves infested by aphids the activity of SOD was higher than in the control plants, with the exception of SOD activity in 48 and 96-h leaves infested by 10 aphids (Figure 4b). In two-month-old leaves infested by 30 aphids the activity of this enzyme clearly increased from 24 to $96 \mathrm{hpi}$, while in the other experimental variants fluctuations were observed in the enzyme activity. At 48 and 96 hpi in leaves infested by 30 aphids the activity of SOD was highest in relation to the other experimental variants. In turn, at 96 hpi SOD activity in one-month-old leaves infested by 10 aphids was significantly lower than in the control. ANOVA showed differences in these results to be highly significant. 


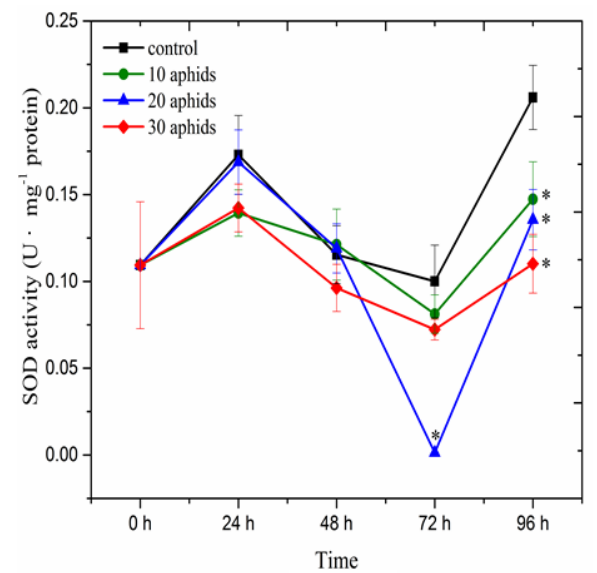

(a)

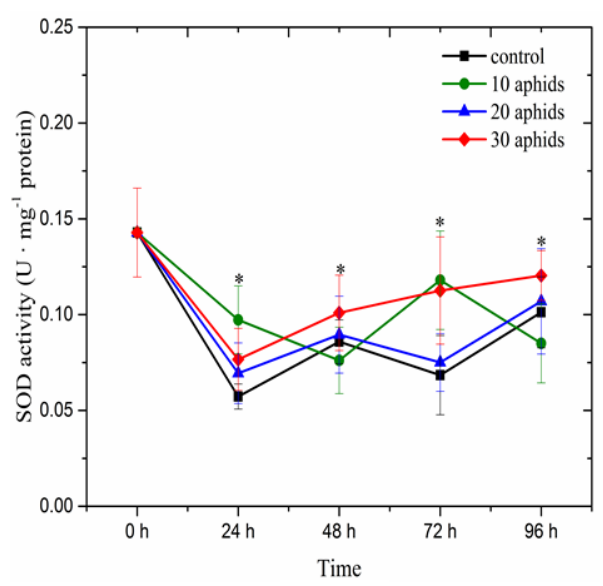

(b)

Figure 4. Superoxide dismutase activity in leaves of one- (a) and two-month-old plants (b) of Asparagus officinalis L. cv. Argenteuil infested by Brachycorynella asparagi (Mordv.) at a varied population size $(10,20,30$ aphids per plant). Values represent means and SE from three independent experiments. The data was statistically analyzed using ANOVA ( $p$-values at $\alpha=0.05)$. In individual figures significant differences are shown using asterisks.

\subsection{Symptoms of Brachycorynella asparagi Infestation on Asparagus officinalis}

Considerable differences in the symptoms caused by B. asparagi were observed on A. officinalis one- and two-month-old plants (Table 1). These differences depended on the number of aphids on A. officinalis plants, the duration of infestation and plant age. Visible symptoms were found in aphid-infested A. officinalis, e.g., twisting of fern tops, shortening of internodes and yellowing of plants as well as growth inhibition. These symptoms were stronger on $A$. officinalis one- month-old plants infested by B. asparagi than two-month-old plants.

Table 1. Symptoms (96 hpi) on one- and two-month-old plants of Asparagus officinalis L. cv. Argenteuil caused by Brachycorynella asparagi (Mordvilko) at a varied population size, i.e., 10, 20, and 30 aphids per plant.

Symptoms
Aphids colonize the tops of the ferns
Gently crimp the tops of the ferns
Shorter internodes
Aphids colonize whole ferns
The top of the ferns are twisted, with shortening
internodes, "rosetting" and the plants turning yellow.
The leaves are shortened and turned blue green

- - one-month old plants of asparagus; —-two-month old plants of asparagus.

\section{Discussion}

The results of the present study revealed stress responses of A. officinalis L. cv. Argenteuil against B. asparagi concerning the level of oxidative stress and antioxidant defense dependent on plant age. The influence of age on the capacity of plants to mobilize a defense mechanism during aphid attack has not been discussed in the current literature. Our results indicate that younger, one-month-old plants induced faster defense responses to B. asparagi than older, two-month-old plants. However, in the early time of infestation of the pest $B$. asparagi, the generation of semiquinone radicals in leaves 
of one- and two-month-old plants demonstrated an increase, whereupon the response was different in those plants. Therefore, reduction of semiquinone radicals (being organic radicals) in 24-h leaves infested by 20 and 30 aphids was found in comparison with the control, which may indicate their incorporation into polymers, such as lignins, to protect the cell wall (Figure 1a,b). From 48 hpi levels of these radicals in infested leaves were significantly higher than in the control. The generation of semiquinone radicals from 48 hpi of feeding by B. asparagi is an important line of defense in A. officinalis leaves. The highest concentration of semiquinone radicals was observed in one-month-old $A$. officinalis leaves infested by 30 aphids at $48 \mathrm{hpi}$, while in two-month old leaves their highest generation was recorded at $72 \mathrm{hpi}$. Summarizing, these results show that in infested leaves of the younger plants the highest generation semiquinone radicals was found earlier than in older leaves. These radicals might have a cytotoxic impact towards B. asparagi and protect $A$. officinalis from damage or react with the $\mathrm{O}_{2}{ }^{\bullet-}$, which relative generation in one-month-old plants infested by B. asparagi was higher than in the two-month-old plants infested by aphids. Moreover, earlier, higher generation of free radicals in one-month-old plants may also indicate their greater sensitivity to B. asparagi.

Semiquinone and phenoxyl radicals in plant cells are formed as a result of oxidation of hydroxyl groups in phenols and polyphenols [30]. The significant role of semiquinone radicals in defense of leguminous plants during an attack of biotic stressors was documented by Morkunas and co-workers also previously [31-37]. For example, concentrations of semiquinone radicals in Acyrthosiphon pisuminfested seedling leaves of Pisum sativum L. cv. Cysterski not only were generally higher than in the control plants, but also significantly increased versus time [16]. Besides, the strong generation and the continuous increase of $\mathrm{O}_{2}{ }^{\bullet-}$ production in aphid-infested seedling leaves of pea from 0 to $96 \mathrm{~h}$ enhanced the defense potential to protect against $A$. pisum.

In this study, $\mathrm{O}_{2}{ }^{\bullet-}$ and $\mathrm{H}_{2} \mathrm{O}_{2}$ relative generation was observed after $B$. asparagi infestation in confocal microscopy. Our results revealed post-infestation enhanced generation of $\mathrm{O}_{2}{ }^{--}$in A. officinalis leaves at all time points after infestation, in comparison to non-colonized plants (Figure 2a-c). Relative generation of $\mathrm{O}_{2}{ }^{\bullet-}$ was lower in infested leaves of two month-old A. officinalis plants than infested leaves of one-month-old plants. In leaves of one-month-old plants most yellow fluorescence spots indicating generation of $\mathrm{O}_{2}{ }^{\bullet-}$ were visible on leaves infested by 20 and 30 aphids. However, the strongest generation was observed in $96-\mathrm{h}$ leaves of one-month-old plants infested by 30 aphids and was visible mostly in the cytoplasm and sporadically in the cell wall regions (Figure 2c). Recent reports indicate the involvement of ROS in a complex signaling network, which is necessary in the induction of defense reactions [38,39]. In addition, in the present study a stronger generation of $\mathrm{H}_{2} \mathrm{O}_{2}$ was observed earlier (at $24 \mathrm{hpi}$ ) in leaves of one-month-old plants than in leaves of two-month-old plants, especially in tissues infested by 30 aphids (Figure 3a-d). A strong emission of green fluorescence was observed both in cell walls and in the cytoplasm of 48-h cells of infested leaves (Figure 3c). In contrast to the generation of $\mathrm{O}_{2}{ }^{\bullet-}$, a stronger emission of green fluorescence was observed in 72 and 96-h leaves of two-month-old plants infested by 30 aphids than in leaves of one-month-old plants infested by 30 aphids, being the most intense in the cytoplasm (Figure 3a-d). In addition, in our previous studies an early, strong generation of $\mathrm{H}_{2} \mathrm{O}_{2}$ at $24 \mathrm{hpi}$ in pea aphid-infested leaves was observed, similarly as at $24 \mathrm{hpi}$ in A. officinalis leaves of one-month-old plants infested by B. asparagi. ROS homeostasis is changed in response to stress; these compounds are regarded as molecules causing damage to cells at a high concentration, as well as ubiquitous signaling molecules at a low concentration, thus participating in recognizing and responding to stress factors [40,41]. Transduction of the signal modifies gene and protein expression levels, leading to physiological responses. ROS are produced in most plant subcellular locations, including the plasma membrane, mitochondria, nucleus, chloroplast and the cell wall [22].

Moreover, in this paper we provide evidence using EPR spectroscopy for strong fluctuations in $\mathrm{Mn}^{2+}$ ion levels versus time in A. officinalis leaves infested by aphids at a varied population size (Figure 1c,d). At 24 hpi the concentration of these ions in one-month-old plants infested by aphids (for all aphid population sizes) was lower than in the control plants (Figure 1c), while in leaves 
of two-month-old plants infested by 20 aphids it was lower only in relation to the control leaves (Figure 1d). These results may indicate the involvement of these ions in the control of $\mathrm{O}_{2}{ }^{\bullet-}$ production. From $48 \mathrm{hpi}$, the concentration of $\mathrm{Mn}^{2+}$ ions was generally higher in infested leaves than in the control. As it was reported by Lidon et al. [42], manganese might control the production of $\mathrm{O}_{2}{ }^{\bullet-}$ (as an isolated ion or as a cofactor of SODs) and directly participate in oxidation processes. Besides, manganese found in different redox states performs different functions. Shenker et al. [43] reported that manganese is involved in both oxygen radical detoxification via its role in SOD activity, and oxygen radical production via its involvement in the photosynthetic pathway. Besides, manganese is also essential for the biosynthesis of chlorophyll (through the activation of specific enzymes), aromatic amino acids (tyrosine) and secondary products, such as lignin and flavonoids [42]. However, it is remarkable in our study that the activity of SOD in one-month-old plants infested by aphids (for all aphid populations) was lower than in the control plants during this experiment (Figure 4a). Perhaps this is related with the maintenance of $\mathrm{O}_{2}{ }^{\bullet-}$ generation at a certain level, which is an important element in the defense strategy of these plants against $B$. asparagi. In contrast, in two-month-old plants infested by aphids the activity of SOD was higher than in the control plants (Figure $4 \mathrm{~b}$ ). In parallel, in these tissues $\mathrm{Mn}^{2+}$ ion levels were higher than in the control plants. An enhanced SOD activity can be an important element in the defense against oxidative stress of two-month-old plants infested by aphids. Analyses of symptoms of B. asparagi infestation on Asparagus officinalis demonstrated that two-month-old plants were less infested than one-month-old plants (Table 1). To prevent ROS toxicity, organisms have evolved antioxidant enzymes, including SOD [44], which activity was studied in this work. Besides, War et al. [25] showed that induction of enzyme activities and the amounts of secondary metabolites were greater in the insect-resistant groundnut genotypes ICGV 86699, ICGV 86031, ICG 2271, and ICG 697 infested with $H$. armigera and A. craccivora than in the susceptible check JL 24 . SOD catalyses the conversion of superoxide radicals to the more stable $\mathrm{H}_{2} \mathrm{O}_{2}$ that is required for long-range cell-to-cell signaling or for passing through membranes [45]. Additionally, SOD represented the first line of defense against ROS [46]. Moreover, Kerchev et al. [15] found that the gene encoding a putative cytosolic $\mathrm{Cu} / \mathrm{ZnSOD}$ was upregulated in Myzus persicae-infested potato plants, whereas the levels of an FeSOD gene transcript gradually declined. It has been suggested that genes involved in oxidative stress are key components of plants infested response [47-49]. In addition, the results obtained by Sytykiewicz [50] suggest that the greater SOD response of seedlings of Zea mays L. Ambrozja (a relatively resistant cultivar) relative to cv. Tasty Sweet (susceptible) seedlings might be an important factor in the ability to alleviate the aphid stimulated oxidative burst and thus may be the basis of Ambrozja's greater ability to survive infestation. Moreover, it was reported that pea aphid colonization led to a significant insect density- and time-dependent enhancement in the rate of $\mathrm{H}_{2} \mathrm{O}_{2}$ and $\mathrm{O}_{2}{ }^{\bullet-}$ production in pea seedlings [16]. Moreover, it was shown that Aphis craccivora at a varied population size (10, 20 and 30 individuals per each soybean plant) caused a burst of $\mathrm{H}_{2} \mathrm{O}_{2}$ generation in the aphid-infested leaves at 12 hpi. Paralleling the $\mathrm{H}_{2} \mathrm{O}_{2}$ accumulation, peroxidase activity in all the infested plants remarkably increased and was significantly higher than that observed in the controls [51]. In turn, Ren et al. [52] observed an $\mathrm{H}_{2} \mathrm{O}_{2}$ flux in mesophyll cells versus time for tobacco samples with different infestation rates of Myzus persicae treatment. Additionally, studies performed by Sytykiewicz [50] evidenced profound intervarietal differences in the accumulation of $\mathrm{H}_{2} \mathrm{O}_{2}$ and relative expression of two catalase genes in maize seedlings challenged by cereal aphids' herbivory.

It should be mentioned here that characteristics of the plant, including organ or tissue identity, developmental stage and genotype, also influence plant response to stress [53]. At specific developmental stages, plants are either more or less sensitive to stressors. The sensitivity stages of development are called windows of sensitivity [54]. Additionally, different adaptive mechanisms can be observed, which depend on the species considered, the organ, the tissue, the age and the exposure intensity of the stress [40]. Moreover, Donovan et al. [55] reported that during plant life stages the levels of plant hormones fluctuate, which affects the induction of defense mechanisms. Besides, different defensive strategies are activated in response to different modes of feeding by insects. 


\section{Materials and Methods}

\subsection{Plant Material}

All experiments were performed on Asparagus officinalis L. cv. Argenteuil, which seeds were provided by the PlantiCo Company in Zielonki near Warszawa (Poland). Asparagus seeds were imbibed in sterile water in an incubator at $23^{\circ} \mathrm{C}$. After $24 \mathrm{~h}$ of imbibition the seeds were transferred to Petri dishes and immersed in a small amount of water in order to support further absorption. After a subsequent $48 \mathrm{~h}$ imbibed seeds were sown in pots of $20 \mathrm{~cm}$ in diameter containing sterilized soil (12 seeds to the pot). One- and two-month-old plants were kept in the growth chamber at $22-23{ }^{\circ} \mathrm{C}, 65 \%$ relative humidity and light intensity of $130-150 \mu$ mole photons $\cdot \mathrm{m}^{-2} \cdot \mathrm{s}^{-1}$ with the 14/10 h (light/dark) photoperiod.

The experimental materials, i.e., leaves of one- and two-month-old A. officinalis, were carefully collected at $0,24,48,72$ and $96 \mathrm{~h}$ post infestation (hpi). Leaves were weighed and then were frozen in liquid nitrogen for subsequent analyses of semiquinone radicals, $\mathrm{Mn}^{2+}$ ions and the activity of superoxide dismutase. Analyses of the generation of hydrogen peroxide and the superoxide anion radical were performed in fresh materials at particular time points for all the variants.

\subsection{Aphids and the Infestation Experiment}

Brachycorynella asparagi (Mordv.) (Mordvilko 1929) (Hemiptera: Aphidoidea) were cultured and supplied by the Department of Entomology and Environmental Protection, the Poznań University of Life Sciences. They were reared on its host, Asparagus officinalis, in the growth chamber at the Department of Plant Physiology, the Poznan University of Life Sciences at a temperature of $21-22{ }^{\circ} \mathrm{C}$, $65 \%$ humidity and the photoperiod of $14 / 10 \mathrm{~h}$ (light/dark) with light intensity of $130-150 \mu \mathrm{M}$ photons $\cdot \mathrm{m}^{-2} \cdot \mathrm{s}^{-1}$.

All plants were infested with 10, 20 and 30 apterous adult females of B. asparagi. Each variant had 4 pots in total. In the experiments one- and two-month-old plants were used. This developmental stage proved to be the most suitable for B. asparagi aphids, which was demonstrated by high daily fecundity (Sobkowiak, unpublished data). Development of aphids is dependent on the age of the plant; generally, aphids better infest developmentally younger plants with high turgor rather than developmentally mature plants. Aphid specimens were carefully transferred to leaves and twigs with a fine paintbrush. The aphid populations were monitored throughout all the experiments. The number of apterous females of B. asparagi remained constant in each experiment, because newly born larvae were removed once a day. The control plants in the experiments were one- and two-month-old plants with no aphids. All the control and aphid-infested plants were put separately into glass boxes $(30 \mathrm{~cm} \times 28 \mathrm{~cm} \times 30 \mathrm{~cm})$ covered with nylon gauze and placed in a growth chamber with the environmental factors controlled.

\subsection{Electron Paramagnetic Resonance (EPR)}

Samples of $1 \mathrm{~g}$ fresh wt. of $A$. officinalis were frozen in liquid nitrogen and lyophilized in a Jouan LP3 freeze dryer. The lyophilized material was transferred to EPR-type quartz tubes of $4 \mathrm{~mm}$ in diameter. Electron paramagnetic resonance measurements were performed at room temperature with a Bruker ELEXSYS X-band spectrometer (Bruker, Rheinstetten, Germany). The EPR spectra were recorded as first derivatives of microwave absorption. A microwave power of $2 \mathrm{~mW}$ and a magnetic field modulation of about $2 \mathrm{G}$ were used for all the experiments to avoid signal saturation and deformation. EPR spectra of free radicals and $\mathrm{Mn}^{2+}$ ions were recorded in the magnetic field range of 3300-3360 G with 4096 data points. In order to determine the number of paramagnetic centers in the samples the spectra were double-integrated and compared with the intensity of the standard $\mathrm{Al}_{2} \mathrm{O}_{3}: \mathrm{Cr}^{3+}$ single crystal with a known spin concentration [16,31-37,56,57]. Before and after the first integration some background corrections of the spectra were made to obtain a reliable absorption signal before the second integration. Finally, EPR intensity data was calculated per $1 \mathrm{~g}$ of dry sample. It should be mentioned here that these tests had been made earlier and revealed that the process of freeze-drying (lyophilization) of the tissue did not cause free radical generation. Moreover, 
determination of the concentration of semiquinone radicals and the levels of $\mathrm{Mn}^{2+}$ ions using EPR was repeated three times, while plant material came from three independent cultures of $A$. officinalis infested by B. asparagi. Leaves (13-14 plants) from each experimental variant were collected to the EPR analysis. Each experiment was repeated three times.

\subsection{Detection of Hydrogen Peroxide Release}

Accumulation of $\mathrm{H}_{2} \mathrm{O}_{2}$ in one- and two-month-old asparagus leaves was detected by staining with a specific fluorescence agent, $2^{\prime}, 7^{\prime}$-dichlorofluorescein diacetate (DCFH-DA, Sigma-Aldrich, Poznań, Poland), following the methods of Małecka et al. [58] modified by Mai et al. [38]. DCFH-DA is non-fluorescent and can passively cross the membrane of live cells and it may be oxidized by $\mathrm{H}_{2} \mathrm{O}_{2}$ to a fluorescent dye detected by a laser confocal microscope. The fluorescence is proportional to the intracellular $\mathrm{H}_{2} \mathrm{O}_{2}$ level. The fresh leaves were submerged in $4 \mu \mathrm{M}$ DCFH-DA dissolved for $12 \mathrm{~h}$ in $3 \mathrm{mM}$ dimethylsulfoxide (DMSO) in $50 \mathrm{mM}$ potassium phosphate buffer, $\mathrm{pH}$ 7.4. The leaves were washed twice with the loading buffer and then were observed under a confocal microscope (Zeiss LSM 510, Axioverd 200 M, Jena, Germany) with a filter set No. 10, excitation $488 \mathrm{~nm}$, emission of $520 \mathrm{~nm}$ or more, and photographed using a digital camera (AxioCam, Zeiss, Jena, Germany). Microscope, laser and photomultiplier settings were held constant during the experiment in order to obtain comparable data. Images were analyzed using the LSM Image Browser software, version 4.2. Moreover, the observation of the generation of $\mathrm{H}_{2} \mathrm{O}_{2}$ under a confocal microscope were carried out on 4 leaves of 5 plants. Each experiment was repeated three times.

\subsection{Detection of Superoxide Anion Radical Release}

The release of $\mathrm{O}_{2}{ }^{\bullet-}$ was detected using a fluorescent dye dihydroethidium (DHE, Sigma-Aldrich), described by Morkunas and Bednarski [35] and Mai et al. [16] with minor modifications. DHE is non-fluorescent and can passively cross the membrane of live cells, and it may be oxidized by $\mathrm{O}_{2}{ }^{\bullet-}$ to a fluorescent dye detected by a laser confocal microscope. The fluorescence is proportional to the intracellular $\mathrm{O}_{2}{ }^{--}$level. The production of $\mathrm{O}_{2}{ }^{\bullet-}$ in one- and two-month-old asparagus leaves was observed following the staining of surfaces with $100 \mu \mathrm{M}$ DHE in $3 \mathrm{mM}$ DMSO after immersing for $12 \mathrm{~h}$ at room temperature in the dark. After rinsing with the $100 \mu \mathrm{M} \mathrm{CaCl}_{2}$ solution, $\mathrm{pH} 4.75$, leaf sections were observed using a Zeiss Axiovert 200M fluorescence microscope (model LSM 510, filter set No.9, excitation 450-490 nm, emission $520 \mathrm{~nm}$ or more, Zeiss, Jena, Germany), and photographed using a digital camera (AxioCam, Zeiss). An argon laser was used for excitation at $488 \mathrm{~nm}$, with emission at 565-615 $\mathrm{nm}$ following background subtraction. All images were obtained at the same depth and were analyzed using the LSM Image Browser software, version 4.2. Moreover, the generation of $\mathrm{O}_{2}{ }^{\bullet-}$ was observed under a confocal microscope on 4 leaves of 5 plants. Each experiment was repeated three times.

\subsection{Extraction and Assay of Superoxide Dismutase Activity}

Frozen leaves $(0.50 \mathrm{~g})$ were homogenized at $4{ }^{\circ} \mathrm{C}$ in $2.0 \mathrm{~mL} 50 \mathrm{mM}$ sodium phosphate buffer (pH 7.0), containing $1.0 \mathrm{mM}$ EDTA, $2 \% \mathrm{NaCl}$ and 1\% PVP (polyvinyl pyrrolidone) and centrifuged at $15,000 \times g$ for $15 \mathrm{~min}$. The activity of SOD (EC 1.15.1.1) was spectrophotometrically assayed by measuring its ability to inhibit the photochemical reduction of nitro blue tetrazolium (NBT) according to Beauchamp and Fridovich [59], as described by Morkunas and Bednarski [35]. The $3 \mathrm{~mL}$ reaction mixture contained $50 \mathrm{mM}$ sodium phosphate buffer (pH 7.8), $13 \mathrm{mM}$ methionine, $75 \mathrm{mM} \mathrm{NBT}, 0.1 \mathrm{mM}$ EDTA and $30 \mu \mathrm{L}$ enzyme extract and $2 \mathrm{mM}$ riboflavin (introduced to the reaction mixture as the last reagent). The reaction was started by switching on the light (two $15 \mathrm{~W}$ fluorescent lamps placed $30 \mathrm{~cm}$ below test tubes) and proceeded for $15 \mathrm{~min}$. Samples without the enzymatic extract in the examined tests were selected so that the absorption difference between the blank and examined tests was about $50 \%$. The amount of the enzyme that caused a $50 \%$ inhibition of NBT reduction was adopted as a unit of SOD activity. The activity of the enzyme was expressed as units per $1 \mathrm{mg}$ of protein $\left(\mathrm{U} \cdot \mathrm{mg}^{-1}\right.$ 
protein). The protein in the samples was determined according to Bradford [60] using bovine serum albumin (Sigma-Aldrich) as a standard. Moreover, leaves of 6-7 plants from each experimental variant were used to determine SOD activity. Each experiment was repeated three times.

\subsection{Statistical Analysis}

All determinations were performed in three independent experiments. Analysis of variance was applied to verify whether means from independent experiments within a given experimental variant were significant. The data was statistically analyzed using ANOVA, StatSoft, Inc. (2009, Poznań University of Life Sciences, Poznań, Poland), STATISTICA, version 9.0, available online: www.statsoft.com. Data shown in the figures represent means of triplicates for each variant and standard errors of mean (SE).

\section{Conclusions}

Defensive reactions in leaves of one- and two-month-old A. officinalis plants to B. asparagi were dependent on the intensity, duration of infestation and age of these plants. In leaves of one-month-old plant infested by aphids, an early higher generation of free radicals, both semiquinone and RFT, was recorded than in leaves of two-month-old plants infested by aphids. Therefore, the level of oxidative stress caused by B. asparagi was higher in leaves of one-month-old plants than in those of two-month-old plants. Strong fluctuations in $\mathrm{Mn}^{2+}$ ion levels versus time in A. officinalis leaves infested by $B$. asparagi indicate the involvement of these ions in the control of $\mathrm{O}_{2}{ }^{--}$production. The activity of SOD may be an important line of defense of two-month-old plants against oxidative stress caused by aphid attack.

Acknowledgments: The present study was supported by the National Science Centre Project (NCN, grant No. 2011/01/B/NZ9/00074).

Author Contributions: Iwona Morkunas: Conceived and designed the experiments, analyzed the data and wrote the paper; Beata Borowiak-Sobkowiak: performed experiments with Brachycorynella asparagi infestation on Asparagus officinalis, supplied the seeds and aphids, wrote the information concerning the aphid Brachycorynella asparagi, and statistical analysis of results; Agnieszka Woźniak: prepared the figures and the graphical abstract, performed experiments and prepared references; Waldemar Bednarski: carried out measurements of concentrations of free radicals and $\mathrm{Mn}^{2+}$ ions using electron paramagnetic resonance spectroscopy, and analyzed the data; Magda Formela: helped in transferring aphids Brachycorynella asparagi onto plants during the preparation of culture, and analyzed published literature; and Sławomir Samardakiewicz: analyzed results from the confocal microscope. All authors read and approved the manuscript.

Conflicts of Interest: The authors declare no conflict of interest.

\section{Abbreviations}

$\begin{array}{ll}\text { EPR } & \text { electron paramagnetic resonance } \\ \text { fr. wt. } & \text { fresh weight } \\ \text { dry wt. } & \text { dry weight } \\ \mathrm{g} & \text { gram } \\ \text { g-values } & \begin{array}{l}\text { the factor describing energy levels of the unpaired electron for the paramagnetic centre in } \\ \mathrm{H}_{2} \mathrm{O}_{2}\end{array} \\ \mathrm{~h} & \text { hydrogen peroxide } \\ \mathrm{hpi} & \text { hour } \\ \mathrm{Mn}{ }^{2+} & \text { hours post infestation } \\ \mathrm{ROS} & \text { manganese ions } \\ \mathrm{SOD} & \text { reactive oxygen species } \\ \mathrm{O}_{2} \bullet & \text { superoxide dismutase } \\ & \text { superoxide anion radical }\end{array}$

\section{References}

1. Brothwell, D.R.; Brothwell, P. Food in Antiquity: A Survey of the Diet of Early Peoples; The Johns Hopkins University Press: Baltimore, MD, USA, 1998; p. 92. 
2. Pitrat, M. Vegetable crops in the Mediterranean Basin with an overview of virus resistance. Adv. Virus Res. 2012, 84, 1-29. [PubMed]

3. Leszczyński, B.; Cone, W.W.; Wright, L.C. Changes in the sugar metabolism of asparagus plants infested by asparagus aphid, Brachycorynella asparagi and green peach aphid, Myzus persicae. J. Agric. Entomol. 1986, 3, 25-30.

4. Stoetzel, M.B. Aphids (Homoptera: Aphididae) colonizing leaves of asparagus in the United States. J. Econ. Entomol. 1990, 83, 1994-2002. [CrossRef]

5. Kerchev, P.I.; Fenton, B.; Foyer, C.H.; Hancock, R.D. Plant responses to insect herbivory: Interactions between photosynthesis, reactive oxygen species and hormonal signalling pathways. Plant Cell Environ. 2012, 35, 441-453. [CrossRef] [PubMed]

6. Klotz, L.O. Oxidative stress, antioxidants and chemoprevention: On the role oxidant-induced signaling in cellular adaptation. In Recent Advances in Redox Active Plant and Microbial Products; Jacob, C., Kirsch, G., Slusarenko, A., Winyard, P.G., Burkholz, T., Eds.; Springer: Dordrecht, The Netherlands; Heidelberg, Germany; New York, NY, USA, 2014; pp. 119-148.

7. Goggin, F.L. Plant-aphid interactions: Molecular and ecological perspectives. Curr. Opin. Plant Biol. 2007, 10, 399-408. [CrossRef] [PubMed]

8. Giordanengo, P.; Brunissen, L.; Rusterucci, C.; Vincent, C.; van Bel, A.; Dinant, S.; Girousse, C.; Faucher, M.; Bonnemain, J.L. Compatible plant-aphid interactions: How aphids manipulate plant responses. C. R. Biol. 2010, 333, 516-523. [CrossRef] [PubMed]

9. Radville, L.; Chaves, A.; Preisser, E.L. Variation in plant defense against invasive herbivores: Evidence for a hypersensitive response in eastern hemlocks (Tsuga canadensis). J. Chem. Ecol. 2011, 37, 592-597. [CrossRef] [PubMed]

10. Prince, D.C.; Drurey, C.; Zipfel, C.; Hogenhout, S.A. The leucine-rich repeat receptor-like kinase brassinosteroid insensitive1-associated kinase 1 and the cytochrome $\mathrm{P} 450$ phytoalexin deficient 3 contribute to innate immunity to aphids in Arabidopsis. Plant Physiol. 2014, 164, 2207-2219. [CrossRef] [PubMed]

11. Jaouannet, M.; Morris, J.A.; Hedley, P.E.; Bos, J.I.B. Characterization of arabidopsis transcriptional responses to different aphid species reveals genes that contribute to host susceptibility and non-host resistance. PLoS Pathog. 2015. [CrossRef] [PubMed]

12. Garcia-Brugger, A.; Lamotte, O.; Vandelle, E.; Bourque, S.; Lecourieux, D.; Poinssot, B.; Wendehenne, D.; Pugin, A. Early signaling events induced by elicitors of plant defenses. Mol. Plant-Microbe Interact. 2006, 19, 711-724. [CrossRef] [PubMed]

13. Moloi, M.J.; van der Westhuizen, A.J. The reactive oxygen species are involved in resistance responses of wheat to the Russian wheat aphid. J. Plant Physiol. 2006, 163, 1118-1125. [CrossRef] [PubMed]

14. Kuśnierczyk, A.; Winge, P.; Jørstad, T.S.; Troczyńska, J.; Rossiter, J.T.; Bones, A.M. Towards global understanding of plant defence against aphids-Timing and dynamics of early Arabidopsis defence responses to cabbage aphid (Brevicoryne brassicae) attack. Plant Cell Environ. 2008, 31, 1097-1115. [CrossRef] [PubMed]

15. Kerchev, P.I.; Fenton, B.; Foyer, C.H.; Hancock, R.D. Infestation of potato (Solanum tuberosum L.) by the peach-potato aphid (Myzus persicae Sulzer) alters cellular redox status and is influenced by ascorbate. Plant Cell Environ. 2012, 35, 430-440. [CrossRef] [PubMed]

16. Mai, V.C.; Bednarski, W.; Borowiak-Sobkowiak, B.; Wilkaniec, B.; Samardakiewicz, S.; Morkunas, I. Oxidative stress in pea seedling leaves in response to Acyrthosiphon pisum infestation. Phytochemistry 2013, 93, 49-62. [CrossRef] [PubMed]

17. Liang, D.; Liu, M.; Hu, Q.; He, M.; Qi, X.; Xu, Q.; Zhou, F.; Chen, X. Identification of differentially expressed genes related to aphid resistance in cucumber (Cucumis sativus L.). Sci. Rep. 2015. [CrossRef] [PubMed]

18. Saxena, I.; Srikanth, S.; Chen, Z. Cross talk between $\mathrm{H}_{2} \mathrm{O}_{2}$ and interacting signal molecules under plant stress response. Front. Plant Sci. 2016. [CrossRef] [PubMed]

19. Maffei, M.E.; Mithofer, A.; Boland, W. Insects feeding on plants: Rapid signals and responses preceding the induction of phytochemical release. Phytochemistry 2007, 68, 2946-2959. [CrossRef] [PubMed]

20. Maffei, M.E.; Mithofer, A.; Arimura, G.I.; Uchtenhagen, H.; Bossi, S.; Bertea, C.M.; Cucuzza, L.S.; Novero, M.; Volpe, V.; Quadro, S.; et al. Effects of feeding Spodoptera littoralis on lima bean leaves. III. Membrane depolarization and involvement of hydrogen peroxide. Plant Physiol. 2006, 140, 1022-1035. [CrossRef] [PubMed] 
21. Morkunas, I.; Woźniak, A.; Formela, M.; Mai, V.C.; Marczak, Ł.; Narożna, D.; Borowiak-Sobkowiak, B.; Kühn, C.; Grimm, B. Pea aphid infestation induces changes in flavonoids, antioxidative defence, soluble sugars and sugar transporter expression in leaves of pea seedlings. Protoplasma 2015. [CrossRef] [PubMed]

22. Gill, S.S.; Tuteja, N. Reactive oxygen species and antioxidant machinery in abiotic stress tolerance in crop plants. Plant Physiol. Biochem. 2010, 48, 909-930. [CrossRef] [PubMed]

23. Zhang, H.J.; Yan, Y.; Peng, L.; Guo, Y.J.; Wan, F.H. Plant defense responses induced by phloem-feeding insects. Acta Entomol. Sin. 2012, 55, 736-748.

24. Menendez, A.I.; Folcia, A.M.; Vizgarra, L.; Romero, A.M.; Martínez-Ghersa, M.A. Impact of plant and aphid stress history on infestation in arugula plants. Entomol. Exp. Appl. 2013, 149, 128-137. [CrossRef]

25. War, A.R.; Paulraj, M.G.; Ignacimuthu, S.; Sharma, H.C. Defensive responses in groundnut against chewing and sap-sucking insects. J. Plant Growth Regul. 2013, 32, 259-272. [CrossRef]

26. Howe, G.A.; Jander, G. Plant immunity to insect herbivores. Annu. Rev. Plant Biol. 2008, 59, 41-66. [CrossRef] [PubMed]

27. Zhao, L.Y.; Chen, J.L.; Cheng, D.F.; Sun, J.R.; Liu, Y.; Tian, Z. Biochemical and molecular characterizations of Sitobion avenae-induced wheat defense responses. Crop Prot. 2009, 28, 435-442. [CrossRef]

28. Wu, J.; Baldwin, I.T. New insights into plant responses to the attack from insect herbivores. Annu. Rev. Genet. 2010, 44, 1-24. [CrossRef] [PubMed]

29. He, J.; Chen, F.; Chen, S.; Lv, G.; Deng, Y.; Fang, W.; Guan, Z.; He, C. Chrysanthemum leaf epidermal surface morphology and antioxidant and defense enzyme activity in response to aphid infestation. J. Plant Physiol. 2011, 168, 687-693. [CrossRef] [PubMed]

30. Barbehenn, R.V.; Poopat, U.; Spencer, B. Semiquinone and ascorbyl radicals in the gut fluids of caterpillars measured with EPR spectrometry. Insect Biochem. Mol. Boil. 2003, 33, 125-130. [CrossRef]

31. Morkunas, I.; Garnczarska, M.; Bednarski, W.; Ratajczak, W.; Waplak, S. Metabolic and ultrastructural responses of lupine embryo axes to sugar starvation. J. Plant Physiol. 2003, 160, 311-319. [CrossRef] [PubMed]

32. Morkunas, I.; Bednarski, W.; Kozłowska, M. Response of embryo axes of germinating seeds of yellow lupine to Fusarium oxysporum. Plant Physiol. Biochem. 2004, 42, 493-499. [CrossRef] [PubMed]

33. Morkunas, I.; Bednarski, W.; Kopyra, M. Defense strategies of pea embryo axes with different levels of sucrose to Fusarium oxysporum and Ascochyta pisi. Physiol. Mol. Plant Pathol. 2008, 72, 167-178. [CrossRef]

34. Morkunas, I.; Formela, M.; Floryszak-Wieczorek, J.; Marczak, Ł.; Narożna, D.; Nowak, W.; Bednarski, W. Cross-talk interactions of exogenous nitric oxide and sucrose modulates phenylpropanoid metabolism in yellow lupine embryo axes infected with Fusarium oxysporum. Plant Sci. 2013, 211, 102-121. [CrossRef] [PubMed]

35. Morkunas, I.; Bednarski, W. Fusarium oxysporum-induced oxidative stress and antioxidative defenses of yellow lupine embryo axes with different sugar levels. J. Plant Physiol. 2008, 165, 262-277. [CrossRef] [PubMed]

36. Bednarski, W.; Ostrowski, A.; Waplak, S. Low temperature short-range ordering caused by $\mathrm{Mn}^{2+}$ doping of $\mathrm{Rb}_{3} \mathrm{H}\left(\mathrm{SO}_{4}\right)_{2}$. J. Phys. Condens. Matter 2010. [CrossRef] [PubMed]

37. Formela, M.; Samardakiewicz, S.; Marczak, Ł.; Nowak, W.; Narożna, D.; Bednarski, W.; Kasprowicz-Maluśki, A.; Morkunas, I. Effects of endogenous signals and Fusarium oxysporum on the mechanism regulating genistein synthesis and accumulation in yellow lupine and their impact on plant cell cytoskeleton. Molecules 2014, 19, 13392-13421. [CrossRef] [PubMed]

38. Mai, V.C.; Drzewiecka, K.; Jeleń, H.; Narożna, D.; Rucińska-Sobkowiak, R.; Kęsy, J.; Floryszak-Wieczorek, J.; Gabryś, B.; Morkunas, I. Differential induction of Pisum sativum defense signaling molecules in response to pea aphid infestation. Plant Sci. 2014, 221, 1-12. [CrossRef] [PubMed]

39. Del Río, L.A. ROS and RNS in plant physiology: An overview. J. Exp. Bot. 2015, 66, 2827-2837. [CrossRef] [PubMed]

40. Le Gall, H.; Philippe, F.; Domon, J.M.; Gillet, F.; Pelloux, J.; Rayon, C. Cell wall metabolism in response to abiotic stress. Plants 2015, 4, 112-166. [CrossRef] [PubMed]

41. Wrzaczek, M.; Brosché, M.; Kangasjärvi, J. ROS signaling loops-Production, perception, regulation. Curr. Opin. Plant Biol. 2013, 16, 575-582. [CrossRef] [PubMed]

42. Lidon, F.C.; Barreiro, M.G.; Ramalho, J.C. Manganese accumulation in rice: Implications for photosynthetic functioning. J. Plant Physiol. 2004, 161, 1235-1244. [CrossRef] [PubMed] 
43. Shenker, M.; Plessner, O.E.; Tel-Or, E. Manganese nutrition effects on tomato growth, chlorophyll concentration, and superoxide dismutase activity. J. Plant Physiol. 2004, 161, 197-202. [CrossRef] [PubMed]

44. Corona, M.; Robinson, G.E. Genes of the antioxidant system of the honey bee: Annotation and phylogeny. Insect Mol. Biol. 2006, 15, 687-701. [CrossRef] [PubMed]

45. Allan, A.C.; Fluhr, R. Two distinct sources of elicited reactive oxygen species in tobacco epidermal cells. Plant Cell 1997, 9, 1559-1572. [CrossRef] [PubMed]

46. Alscher, R.G.; Erturk, N.; Heath, L.S. Role of superoxide dismutases (SODs) in controlling oxidative stress in plants. J. Exp. Bot. 2002, 53, 1331-1341. [CrossRef] [PubMed]

47. Moran, P.J.; Cheng, Y.; Cassell, J.L.; Thompson, G.A. Gene expression profiling of Arabidopsis thaliana in compatible plant-aphid interactions. Arch. Insect Biochem. Physiol. 2002, 51, 182-203. [CrossRef] [PubMed]

48. Xia, X.; Shao, Y.; Jiang, J.; Ren, L.; Chen, F.; Fang, W.; Guan, Z.; Chen, S. Gene expression profiles responses to aphid feeding in chrysanthemum (Chrysanthemum morifolium). BMC Genom. 2014. [CrossRef] [PubMed]

49. Lei, J.; Zhu-Salzman, K. Enhanced aphid detoxification when confronted by a host with elevated ROS production. Plant Signal. Behav. 2015, 10, e1010936. [CrossRef] [PubMed]

50. Sytykiewicz, H. Transcriptional responses of catalase genes in maize seedlings exposed to cereal aphids' herbivory. Biochem. Syst. Ecol. 2015, 60, 131-142. [CrossRef]

51. Mai, V.C.; Tran, N.T.; San Nguyen, D. The involvement of peroxidases in soybean seedlings' defense against infestation of cowpea aphid. Arthropod-Plant Interact. 2016, 10, 283-292. [CrossRef]

52. Ren, G.; Wang, X.; Chen, D.; Wang, X.; Liu, X. Effects of aphids Myzus persicae on the changes of $\mathrm{Ca}^{2+}$ and $\mathrm{H}_{2} \mathrm{O}_{2}$ flux and enzyme activities in tobacco. J. Plant Interact. 2014, 9, 883-888. [CrossRef]

53. Bray, E.A.; Baily-Serres, J.; Weretilnyk, E. Responses to Abiotic Stresses. In Biochemistry and Molecular Biology of Plants; Buchanan, B., Gruissem, W., Jones, R., Eds.; American Society of Plant Physiologists: Rockville, MD, USA, 2000; pp. 1158-1203.

54. Gaspar, T.; Franck, T.; Bisbis, B.; Kevers, C.; Jouve, L.; Hausman, J.F.; Dommes, J. Concepts in plant stress physiology. Application to plant tissue cultures. Plant Growth Regul. 2002, 37, 263-285. [CrossRef]

55. Donovan, M.P.; Nabity, P.D.; DeLucia, E.H. Salicylic acid-mediated reductions in yield in Nicotiana attenuata challenged by aphid herbivory. Arthropod-Plant Interact. 2013, 7, 45-52. [CrossRef]

56. Rucińska, R.; Waplak, S.; Gwóźdź, E.A. Free radical formation and activity of antioxidant enzymes in lupin roots exposed to lead. Plant Physiol. Biochem. 1999, 37, 187-194. [CrossRef]

57. Garnczarska, M.; Bednarski, W.; Morkunas, I. Re-aeration-induced oxidative defenses in hypoxically pretreated lupine roots. J. Plant Physiol. 2004, 16, 415-422. [CrossRef] [PubMed]

58. Małecka, A.; Piechalak, A.; Tomaszewska, B. Reactive oxygen species production and antioxidative defense system in pea root tissues treated with lead ions: The whole roots level. Acta Physiol. Plant 2009, 31, 1053-1063. [CrossRef]

59. Beauchamp, C.; Fridovich, I. Superoxide dismutase: Improved assays and an assay applicable to acrylamide gels. Anal. Biochem. 1971, 44, 276-287. [CrossRef]

60. Bradford, M.M. A rapid and sensitive method for the quantitation of microgram quantities of protein utilizing the principle of protein-dye binding. Anal. Biochem. 1976, 72, 248-254. [CrossRef]

(C) 2016 by the authors; licensee MDPI, Basel, Switzerland. This article is an open access article distributed under the terms and conditions of the Creative Commons Attribution (CC-BY) license (http:/ / creativecommons.org/licenses/by/4.0/). 